\title{
LOKASI-LOKASI POTENSIAL BAGI PANTI BENIH TERAPUNG IKAN KARANG DI SELATAN P. BINTAN DAN KARIMUN JAWA
}

\author{
Wardana Ismail $^{*}$, Supriyono Eko Wardoyo ${ }^{\star)}$ dan Bambang Priono*)
}

\begin{abstract}
ABSTRAK
Survai lokasi bagi penempatan Panti Benih Terapung ikan karang telah dilakukan di perairan Selatan P. Bintan Karimun Jawa, pada periode Mei-Juli 1996. Penelitian ini dilakukan atas dasar parameter yang telah ditentukan baik teknis maupun nonteknis, meliputi kualitas air, kesuburan air, ekosistem, ketersediaan induk dan kemudahan mencapai lokasi, bahan KJA, tenaga kerja, keamanan, sarana, masyarakat, pasar. Dalam penelitian di lapangan tim peneliti dilengkapi dengan alat GPS (Global Positioning System) untuk menentukan posisi (Lintang dan Bujur) yang tepat di laut.

Dengan perbandingan bobot parameter teknis dengan nonteknis 5,5:4,5 serta ranking penilaian antara 1-5 tergantung pentingnya parameter yang diamati dalam penentuan lokasi Panti Benih, maka diperoleh hasil bahwa perairan Selatan P. Bintan (Kepulauan Riau) memiliki lokasi yang lebih baik daripada perairan kepulauan Karimun Jawa. Khusus perairan di Selatan P. Bintan, lokasi sekitar perairan Pulau Sirai memiliki skor paling tinggi, yaitu 512,5. Dengan demikian, bagi penempatan Panti Benih Terapung ikan karang maka lokasi perairan Pulau Sirai, Selatan P. Bintan di Kepulauan Riau sangat potensial untuk dikembangkan.
\end{abstract}

ABSTRACT: Potential sites for floating hatchery of coral fish in Southern Bintan Island, Riau and Karimun Jawa waters.by: Wardana Ismail, Supriyono Eko Wardoyo and Bambang Priono.

Site selection surveys for floating hatchery of coral fish were conducted from May to July 1996 in Riau and Karimun Jawa waters. Surveys were conducted based on technical and non-technical factors, such as water quality, fertility, ecosystem, broodstock, and accessibility, man power, security, infrastructure, society, and market demand. The survey team was equipped with GPS (Global Positioning System) to determine accurate positions in the sea

Values of the technical and nontechnical factor were weighted 5.5:4.5 and ranking scores were between 1-5 depending on the importance of observed parameters. It was resulted that Southern Bintan Island waters were better than Karimun Jawa. In Southern Bintan Island, location surrounding Sirai Island had the highest score $(512,5)$ compare to other locations, that means Sirai Island waters are very potential for the development of floating hatchery for coral fish.

KEYWORDS: Floating Hatchery, site selection, coral fish, Bintan Island, Karimun Jawa.

\section{PENDAHULUAN}

Budidaya ikan laut sangat prospektif pengembangannya di Indonesia yang memiliki sumber daya perairan dan beragam komoditasnya. Namun demikian sampai saat ini sebagian pasokan benih bagi kegiatan budidaya laut khususnya ikan karang, masih mengandalkan pada benih alam yang tidak terjamin mutu, jumlah dan kontinyuitas ketersediaannya. Teknologi pembenihan beberapa jenis ikan karang seperti kakap putih, kerapu lumpur, kerapu macan, kerapu sunu, beronang, kerapu bebek, atau lemak telah dikuasai (Sugama \& Wiyono, 1955). Namun demikian pembenihan buatan yang dilakukan di darat (land based) masih menghadapi kendala pemeliharaan larva, penyediaan jasad pakan dan pendederan di samping memerlukan lahan dan fasilitas pembenihan dengan biaya tinggi. Panti benih terapung ikan karang semi alami adalah salah satu usaha penanggulangan masalah tersebut. Pemanfaatan sumber daya alam yaitu

\footnotetext{
Peneliti pada Pusat Penelitian dan Pengembangan Perikanan
} 
lingkungan yang bebas cemaran, pakan alami yang sesuai dengan kebutuhan dan kualitas air akan menunjang keberhasilan dan pengembangan panti benih semi alami ini.

Sejak tahun 1978 di wilayah Riau telah berkembang budidaya ikan kerapu dengan sistem Keramba Jaring Apung (KJA). Usaha ini berkembang karena dukungan pasar di P. Bintan, Batam, Singapura dan Hongkong. Hingga saat ini tercatat sekitar 1500 kurungan apung (Mintardjo et al., 1995) telah dikembangkan di perairan tersebut. Jenis-jenis ikan yang dibudidayakan adalah kerapu sunuk, kerapu lumpur, kakap merah, ikan lemak dan kakap putih (Lamidi, 1992; Asmaneli \& Masril, 1992; Mintardjo, 1995). Usaha budidaya tersebut memerlukan pasok benih yang cukup besar, yang diperkirakan mencapai 3 juta ekor ikan/tahun. Untuk ikan kakap putih saja, P.T. Buru Karimun Mandiri memerlukan 6 ton per tahun (Elon, 1995). Pengembangan panti-panti terapung di wilayah usaha budidaya ikan tentu akan sangat menguntungkan karena semakin pendeknya jarak pasok benih. Hal ini menguntungkan selain harga benih yang menjadi lebih rendah, juga mutu benih akan lebih tinggi karena benih tidak mengalami stres karena pengaruh pengangkutan. Untuk mendukung pengembangan panti-panti benih tersebut tentunya diperlukan lokasi yang tepat, yang memenuhi persyaratan produksi benih ikan.

Ismail et al. (1996) telah melakukan penelitian untuk menyeleksi lokasi yang sesuai bagi reservat ikan di Kepulauan Riau, dan hasilnya perairan Duku, Dompak, Muara Sungai Betung adalah yang paling ideal bagi penempatan KJA reservat sebagai penampungan induk kerapu. Dari hasil penelitian tersebut diperkirakan Kepulauan Riau juga sesuai bagi penempatan KJA sebagai panti benih terapung. Dalam pemilihan lokasi, Ismail et al. (1966) melakukan penilaian terhadap karakter perairan, dengan mangacu pada persyaratan suatu perairan bagi reservat ikan. Metode ini diperkirakan dapat pula digunakan untuk menilai kesesuaian suatu lokasi perairan bagi panti benih, dengan menggunakan persyaratan panti benih sebagai acuan.

Kegiatan penelitian identifikasi perairan yang potensial untuk penempatan KJA panti benih berikut pengembangannya dilaksanakan di dua lokasi yaitu di perairan Kepulauan Riau, Propinsi Riau dan perairan Kepulauan Karimun Jawa,
Kabupaten Jepara, Propinsi Jawa Tengah. Sehubungan dengan SK Menhut No. 123/KptsII/1986 yang menetapkan bahwa Kepulauan Karimun Jawa sebagai daerah cagar alam, serta SK Menhut No. 116/Menhut II/1988 yang menyatakan Kepulauan Karimun Jawa merupakan 'Taman Laut Nasional (TLN) yang terbagi atas empat mintakad (wilayah), yaitu: 1). mintakad inti, 2). mintakad perlindungan, 3). mintakad pemanfaatan, dan 4). mintakad penyangga, maka lokasi yang digunakan dalam penelitian ini dipilih yang terletak di mintakad pemanfaatan. Hasil penelitian diharapkan dapat dimanfaatkan untuk pengembangan teknologi KJA panti benih semi alami dan pemanfaatan sumber daya alam perairan untuk perikanan budidaya.

\section{BAHAN DAN METODE PENELITIAN}

Lokasi-lokasi penelitian di perairan Selatan Bintan dan Karimun Jawa dipilih berdasarkan peta wilayah kepulauan Riau dan Karimun Jawa. Berdasarkan peta tersebut, lokasi dipilih dengan mempertimbangkan beberapa faktor penting seperti lokasi selat yang biasanya cocok untuk KJA, adanya pemukiman penduduk dan bukan alur lalulintas kapal-kapal besar, serta keberadaan usaha budidaya ikan karang. Penajaman seleksi lokasi penelitian dilakukan melalui wawancara dengan aparat terkait atau nelayan setempat yang memiliki informasi mengenai sifat dan kondisi perairan serta menguasai permasalahan budidaya ikan di daerah tersebut.

Berdasarkan pertimbangan yang telah disebutkan, lokasi yang dipilih untuk diamati potensinya dalam penelitian ini adalah: a) Selat antara Pulau Alang dan Pulau Mantang, b) Selat antara Pulau Kekip dan Pulau Mantang, dan c) Selat antara Pulau Sirai dan Pulau Senjolong Besar, untuk perairan Selatan P. Bintan (Gambar 1), serta d) selat antara P. Menjangan Besar dan P. Menjangan Kecil, e) Teluk Legon Boyo, dan f) selat antara P. Karimun Jawa dengan P. Menjangan Besar untuk perairan Karimun Jawa (Gambar 2). Lokasi-lokasi tersebut di samping merupakan selat yang umumnya cocok untuk KJA juga merupakan daerah pemukiman penduduk sehingga dapat menunjang berjalannya panti benih serta tidak di lalui kapal-kapal besar yang kemungkinan dapat menimbulkan pencemaran. 


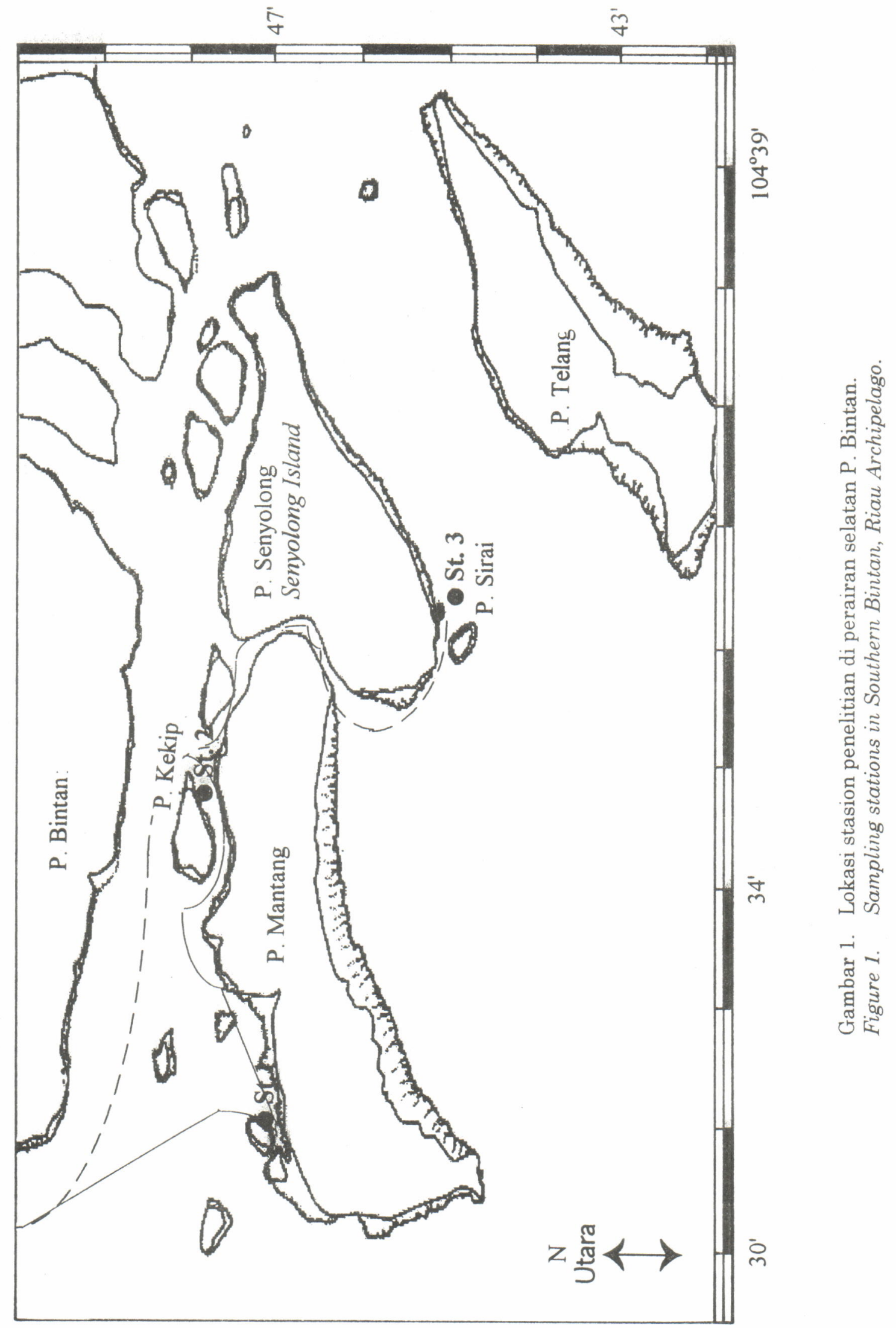




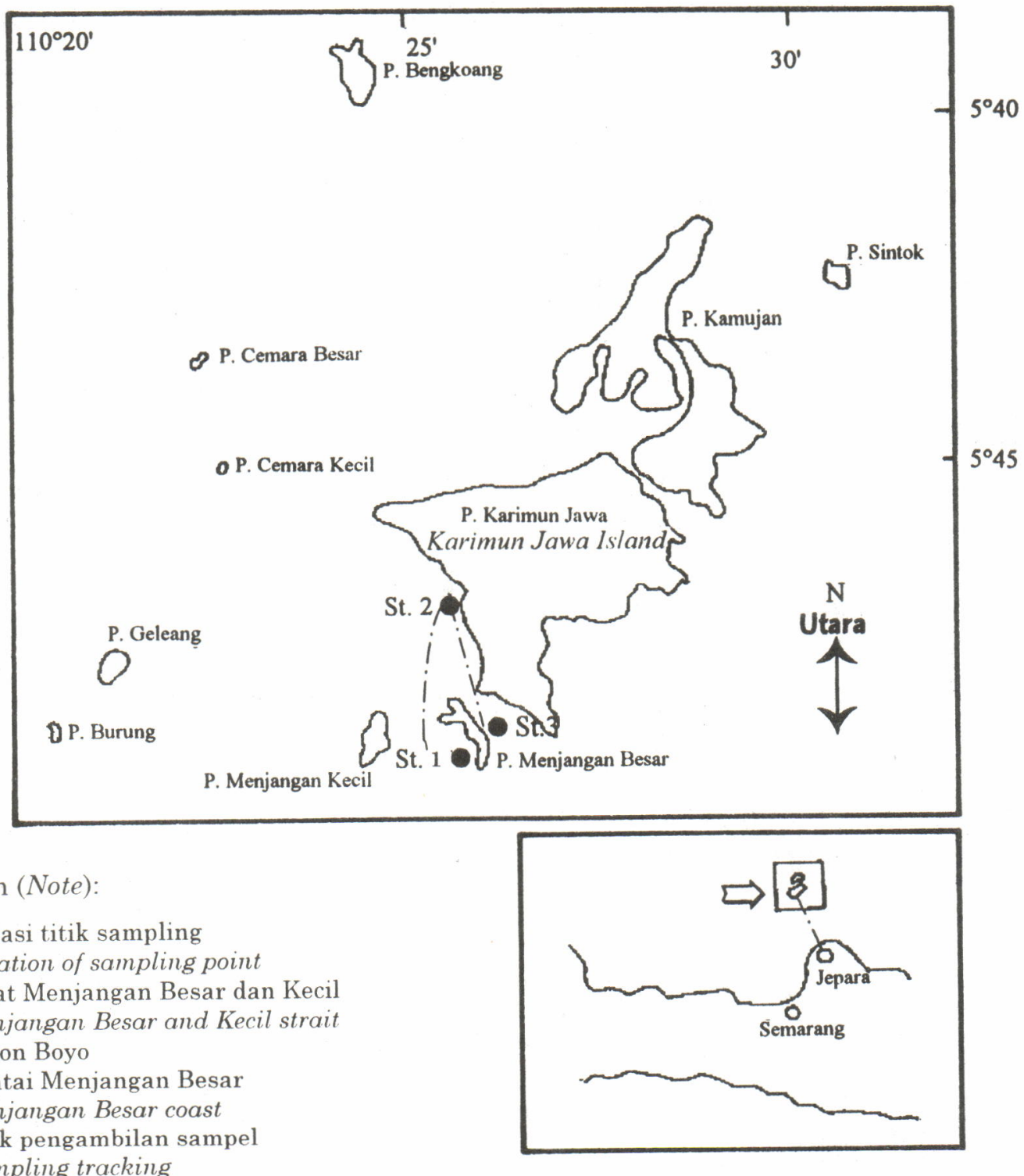

Keterangan (Note):

Lokasi titik sampling

Location of sampling point

St. 1 : Selat Menjangan Besar dan Kecil

Menjangan Besar and Kecil strait

St. 2 : Legon Boyo

St. 3 : Pantai Menjangan Besar

Menjangan Besar coast

-.- : Trak pengambilan sampel

Sampling tracking

Gambar 2. Lokasi stasion sampling di perairan Karimun Jawa.

Figure 2. Sampling location of Karimun Jawa waters.

Dalam seleksi lokasi dilakukan pengukuran dan penilaian parameter teknis dan nonteknis. Masing-masing parameter tersebut diberi perbandingan bobot berbeda, yaitu untuk faktor teknis 5,5 dan nonteknis 4,5 dengan nilai 1,3 , dan 5 tergantung pentingnya parameter tersebut dalam penentuan lokasi KJA panti benih. Skor terakhir dari suatu lokasi adalah jumlah skor parameter-parameter yang didapatkan dari hasil perkalian antara nilai dan bobot (skor parameter = nilai $\mathrm{x}$ bobot). Akhirnya akan didapatkan skor yang berbeda pada setiap lokasi yang diteliti. Skor yang tertinggi dari suatu lokasi adalah merupakan lokasi yang terpilih. Sistem skoring seperti tersebut dalam pemilihan lokasi mengacu metode untuk pemilihan lokasi bagi keramba jaring apung reservat yang dilakukan oleh Ismail et al. (1996).

Dalam penelitian di lapangan tim peneliti dilengkapi dengan alat GPS (Global Positioning System) untuk menentukan posisi (Lintang dan Bujur) di laut, dan alat-alat lain untuk penentuan (pengamatan) kualitas air.

Parameter teknis yang diamati adalah kualitas air, kesuburan perairan, morfologi 
Ismail, W.; Supriyono, E.W.; dan Bambang P.

perairan dan ekosistem, serta ketersediaan induk ikan karang, sedangkan parameter nonteknis adalah aksesibilitas lokasi, ketersediaan bahan
KJA, tenaga kerja, keamanan, ketersediaan sarana pendukung, perilaku masyarakat sekitar, dan permintaan benih ikan (Tabel 1).

Tabel 1. Penentuan nilai berdasarkan parameter teknis dan non teknis.

Tabel 1. Scoring based on techical and non technicaal parameters.

\begin{tabular}{ccccc}
\hline Parameter (Parameters) & \multicolumn{3}{c}{ Nilai (Score) } \\
\cline { 2 - 4 }
\end{tabular}

I. Teknis (Technical aspects) (bobot/weight : 5,5)

1. Kualitas air (Water quality) :

- Kedalaman (Depth)

- Kecerahan (Transparancy)

- Salinitas (Salinity)

- Oksigen terlarut (Disolved Oxygen)

- $\mathrm{pH}$

- Suhu air (Water temperature)

- Arus air (Water current)

- Gelombang (Waves)

- Tanah dasar (Bottom soil)

$$
\begin{gathered}
<3 \mathrm{~m} \\
<1 \mathrm{~m} \\
<20 \mathrm{ppt} \\
<4 \mathrm{ppm} \\
<5 \\
<25 \mathrm{atau}>32 \\
>20 \mathrm{~cm} / \mathrm{dt} \\
>30 \mathrm{~cm} \\
\text { Lumpur (clay) }
\end{gathered}
$$

$$
\text { sedikit (low) }
$$$$
\text { sedikit (low) }
$$

Varlety and density of plankton

Keragaan dan jumlah ikan rucah Density and abundance of trash fish

3. Morfologi dan ekosistem (Morphology and ecosystem)

- Morfologi (Morphology)

- Keberadaan bakau, lamun, dan terumbu karang (Density of mangrove, seagrass, and coral reefs)

- Jarak ke pantai (Dinstance to coast line)

4. Ketersediaan induk ikan karang Availability of coral fish broodstock

$$
\begin{aligned}
& \text { terbuka (open) } \\
& \begin{array}{c}
\text { tidak ada/jarang } \\
\text { low } \\
<50 \mathrm{~m}
\end{array}
\end{aligned}
$$

sulit/sedikit (low)

$3-5 \mathrm{~m}$
$1-3 \mathrm{~m}$
$20-30 \mathrm{ppt}$
$5-6 \mathrm{ppm}$
$5-7$
$25-27$
$10-20 \mathrm{~cm} / \mathrm{dt}$
$20-30 \mathrm{~cm}$
sanpur berpasir
sandy clay

$>5 \mathrm{~m}$

$>3 \mathrm{~m}$

$>30 \mathrm{ppt}$

$>7$ ppm

$>7$

28-32

$<10 \mathrm{~cm} / \mathrm{dt}$

$<20 \mathrm{~cm}$

Pasir lumpur sand

$$
\begin{aligned}
& \text { sedang (moderate) banyak (high) } \\
& \text { sedang (moderate) banyak (high) }
\end{aligned}
$$

cukup terlindung moderately closed cukup padat moderate

$$
>200 \mathrm{~m}
$$$$
50-200 \mathrm{~m}
$$

terlindung closed padat (high)

cukup mudah/ mudah/banyak sedang (moderate) high

II. Nonteknis (Non technical aspects) (bobot/weight : 4.5)

1. Aksesibilitas lokasi (Accessability of location)

2. Ketersediaan bahan KJA Availability of materials for cage

3. Tenaga kerja (Availability of labour)

4. Keamanan (Security)

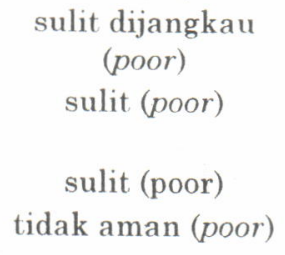

agak sulit dijangkau (fair) agak sulit (fair)

agak sulit (fair) agak aman (fair) mudah dijangkau (good) mudah (good)

mudah (good) aman (good) 
Tabel 1. Lanjutan

Table 1. Continued

\begin{tabular}{|c|c|c|c|}
\hline \multirow{2}{*}{ Parameter (Parameters) } & \multicolumn{3}{|c|}{ Nilai (Score) } \\
\hline & 1 & 3 & $\mathbf{5}$ \\
\hline $\begin{array}{l}\text { 5. Ketersediaan sarana pendukung: listrik, } \\
\text { komunikasi, pasar, pabrik es, dll. } \\
\text { Availability of supporting facilities: } \\
\text { electricity, communication, market, ice } \\
\text { making plant, etc.) }\end{array}$ & $\begin{array}{l}\text { tidak ada/sedikit } \\
\text { poor }\end{array}$ & $\begin{array}{l}\text { sebagian tersedia } \\
\text { fair }\end{array}$ & $\begin{array}{l}\text { lengkap } \\
\text { good }\end{array}$ \\
\hline $\begin{array}{l}\text { 6. Hasrat petani ikan untuk maju } \\
\text { Attitude of fish farmers }\end{array}$ & rendah (poor) & sedang (fair) & tinggi (good) \\
\hline $\begin{array}{l}\text { 7. Permintaan benih ikan (Demand for fish } \\
\text { seed) }\end{array}$ & $\begin{array}{l}\text { tidak ada/ } \\
\text { rendah }(l o w)\end{array}$ & sedang (moderate) & tinggi (high) \\
\hline
\end{tabular}

\section{HASIL DAN PEMBAHASAN}

Hasil penelitian terhadap parameter-parameter yang diukur menunjukkan bahwa lokasi selatan P. Bintan mendapatkan skor 979 untuk faktor teknis dan 319,5 untuk faktor nonteknis atau total 1298,5, sedangkan lokasi P. Karimun Jawa memperoleh skor total 950,5 yang terdiri atas 793 dari faktor teknis dan 157,5 dari nonteknis (Tabel 2 dan 3). Dari tabel-tabel tersebut terlihat bahwa daerah selatan P. Bintan mempunyai potensi yang lebih tinggi untuk digunakan sebagai lokasi panti benih. Untuk daerah selatan P. Bintan, dari tiga lokasi yang diamati ternyata lokasi di antara P. Sirai dan P. Senjolong Besar adalah yang terbaik karena memperoleh skor 364 untuk faktor teknis, dan 148,5 untuk faktor non teknis. Adapun untuk perairan Karimun Jawa, lokasi di dekat P. Menjangan Besar adalah yang terbaik dibandingkan dua lokasi lain, walaupun skornya masih jauh di bawah skor untuk lokasi di dekat P. Sirai di selatan P. Bintan.

Kedalaman perairan di enam lokasi di kedua wilayah (selatan P. Bintan dan Karimun Jawa) berkisar antara 5-16 m, dan semuanya memenuhi syarat bagi penempatan panti benih terapung. Kecerahan dan suhu air di selatan P. Bintan memang sedikit lebih rendah (masing-masing sekitar 2-2,5 $\mathrm{m}$ dan $27-27,5^{\circ} \mathrm{C}$ ) dibandingkan dengan di Karimun Jawa yang mencapai masingmasing 5-7 $\mathrm{m}$ dan $29-31^{\circ} \mathrm{C}$. Kedua wilayah perairan pada umumnya berdasar pasir, kecuali lokasi P.Alang yang mempunyai dasar lumpur dan lokasi Boyo yang mempunyai dasar lumpur berpasir. Warna air juga rata-rta hijau atau hijau kebiruan yang jernih kecuali lokasi di dekat P.Kekip yang terlihat keruh.
Arus air di Karimun Jawa mempunyai skor yang lebih rendah dibandingkan dengan selatan Bintan. Selebihnya, salinitas, oksigen terlarut dan $\mathrm{pH}$ di ke enam lokasi dinilai cukup bagus bagi kehidupan ikan karang. Dari segi morfologi, lima lokasi dinilai cukup bagus karena merupakan selat yang tertutup, hanya lokasi di $\mathrm{P}$. Menjangan Kecil yang kurang memenuhi syarat. Secara umum, perairan Karimun Jawa tidak sebaik selatan P. Bintan dilihat dari jenis dan kerapatan plankton (Tabel 4), ketersediaan ikan rucah dan keberadaan hutan bakau. Namun demikian, terumbu karang hanya ditemukan di Karimun Jawa, tidak di selatan P. Bintan. Selain itu, perairan Karimun Jawa tidak didukung dengan ketersediaan induk ikan karang, kemudahan dalam mendapatkan tenaga kerja maupun bahan untuk KJA serta fasilitas pendukung lainnya. Lebih jauh, wilayah ini mempunyai aksesibilitas yang rendah, keamanan yang kurang terjamin, perilaku masyarakat petani ikan yang masih rendah dan permintaan benih yang juga rendah.

Untuk lokasi selatan P. Bintan, perairan di dekat P. Sirei memang lebih unggul dalam ketersediaan plankton sebagai sumber jasad pakan bagi benih ikan, ketersediaan induk, material untuk KJA, tenaga kerja, dan fasilitas pendukung lainnya. Di samping itu, permintaan pasar akan benih di daerah tersebut memang tinggi dan ini mempengaruhi sikap petani ikan dalam merespon teknologi pembenihan ikan.

Adapun untuk lokasi Karimun Jawa, satusatunya keunggulan lokasi P. Menjangan Besar dibandingkan dengan dua lokasi lainnya adalah perilaku masyarakat petani ikan di sekitar lokasi percobaan, yang tampak memberikan respon positif. 


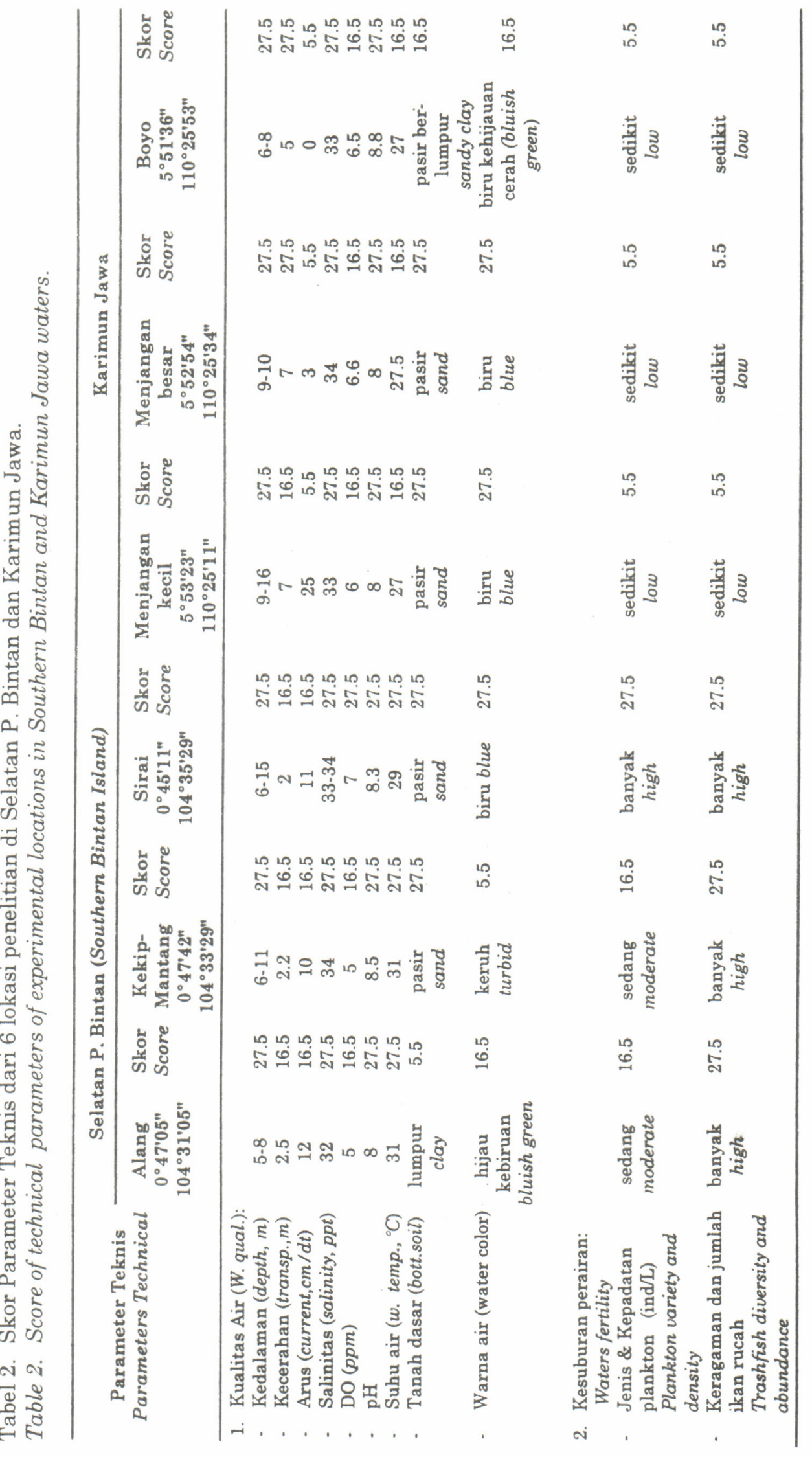




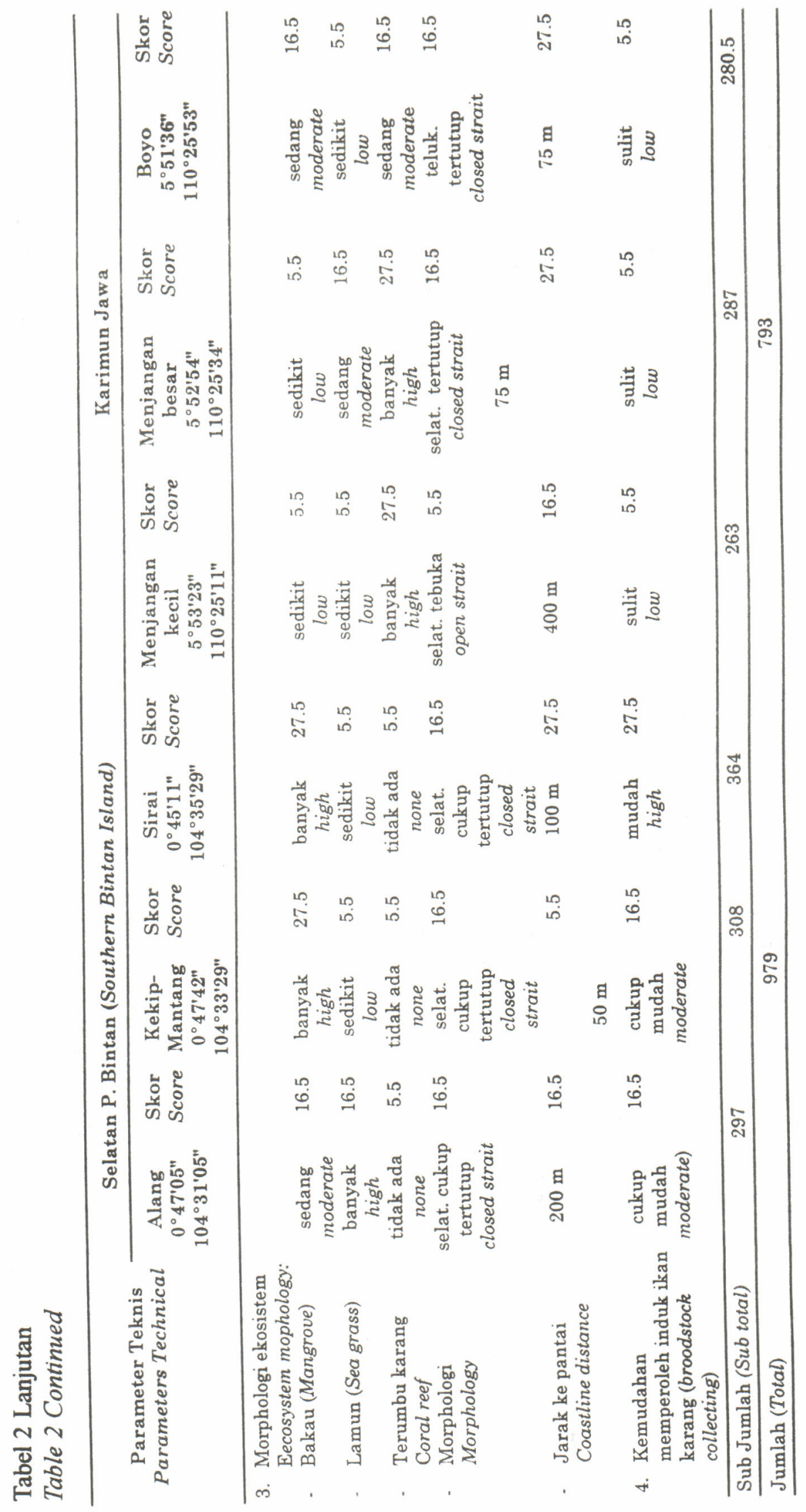




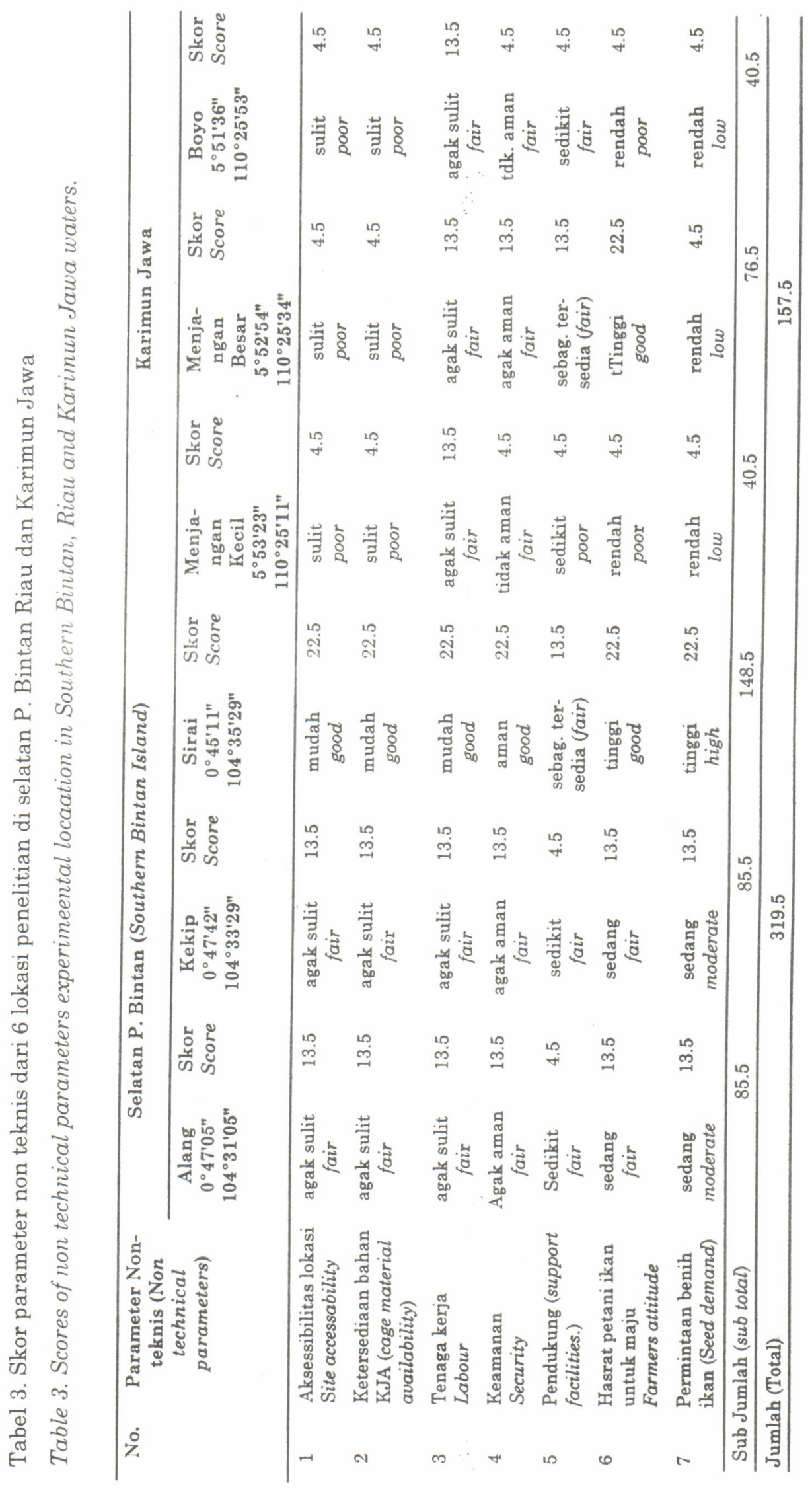


Jurnal Penelitian Perikanan Indonesia Vol.IV No.1 Tahun 1998

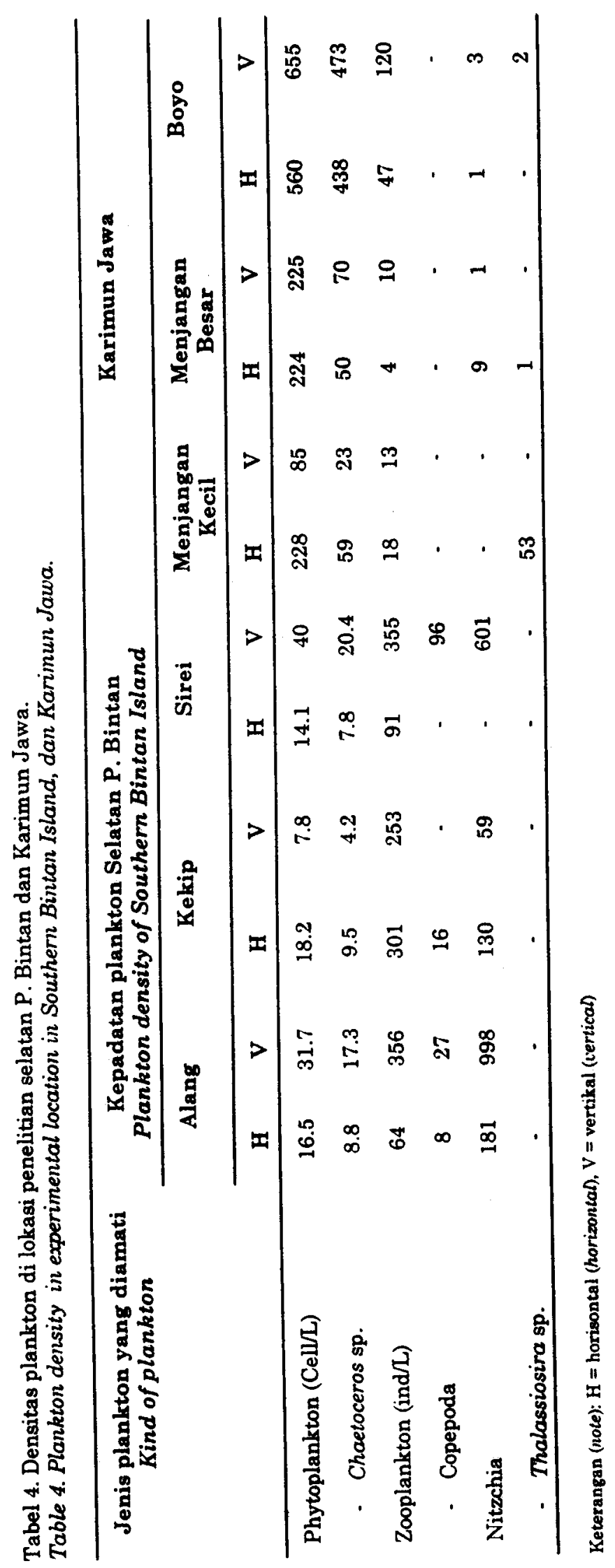




\section{KESIMPULAN DAN SARAN}

\section{Kesimpulan}

Dari penelitian identifikasi potensi lokasi bagi penempatan panti benih terapung semi alami di laut, maka dapat disimpulkan sebagai berikut:

a. Daerah Selatan P. Bintan (Kepulauan Riau) berdasarkan penelitian ini ternyata memiliki lokasi yang lebih baik untuk panti benih terapung ikan karang daripada daerah Karimun Jawa, baik ditinjau dari aspek teknis maupun nonteknis.

b. Lokasi sekitar P. Sirei yang ada di selatan P. Bintan (Kepulauan Riau) merupakan lokasi terbaik di antara lokasi-lokasi yang telah disurvai (skor 512,5), baik dibandingkan dengan lokasi lain di selatan P. Bintan (P. Alang 382,5; Kekip 393,5) sendiri maupun lokasi percobaan di Karimun Jawa (Menjangan Kecil 303,5; Menjangan Besar 363,5; Boyo 293,5). Lokasi di P. Sirei memiliki beberapa keunggulan, di antaranya adalah: terdapat pengusaha eksportir ikan kerapu, kondisi teknis dan nonteknisnya sangat menguntungkan, banyak tersedia induk-induk kerapu yang dapat dibeli dan dipesan dari pengusaha tersebut dan tersedia sarana komunikasi (telepon dan radio panggil) yang penting bagi kontrol kegiatan panti benih.

c. Untuk Kepulauan Karimun Jawa, lokasi Menjangan Besar merupakan lokasi terbaik bagi penempatan panti benih terapung semi alami ikan-ikan karang, walaupun skornya jauh di bawah lokasi P. Sirei di selatan P. Bintan, Riau.

\section{Saran}

Dari hasil penelitian ini disarankan pembangunan panti benih terapung di Sirai, selatan
P. Bintan. Namun sebelum pembangunan dilaksanakan perlu diteliti lebih rinci mengenai arus dan profil dasar pantai sehingga dapat dilakukan penempatan jangkar, serta desain dan konstruksi rakit yang tepat.

\section{DAFTAR PUSTAKA}

Asmanelli dan Masril. 1992. Survai penyakit ikan laut dalam keramba jaring apung di perairan Galang dan Batam. Sub-Balai Penelitian Budidaya Perikanan Pantai (Internal report).

Badrudin, E.M. Amin, T. Achmad dan W.Ismail. 1991. Potensi pengembangan budidaya keramba jaring apung laut di perairan Sendang Biru, Karimun Jawa, dan Teluk Banten. Bull.Pen. Perikanan Edisi Khusus no:3:1-18.

Elon Sugiri. 1995. Kondisi dan permasalahan pengendalian budidaya laut di daerah. Prosiding Temu Usaha Pemasyarakatan Teknologi Keramba Jaring Apung Bagi Budidaya Laut. Puslitbang PerikananFKPPA Agri Business Club : 253-274

Ismail.W., P.T.Imanto, B.Priono dan Lamidi. 1996. Pemilihan lokasi ideal bagi penempatan KJA reservat di perairan kep Riau, Lombok, dan Sumbawa. Jurnal Penelitian Perikanan Indonesia Vol.II no 4:1-22

Lamidi. 1992. Survei lokasi budidaya laut di perairan Bintan Selatan dan Bintan Timur Sub-Balai Penelitian Budidaya Perikanan Pantai (Internal report).

Mintardjo M.K., P. Hartono, dan Notowinarto. 1995. Prospek pengembangan budidaya laut di Kab. Bengkalis dan sekitarnya. Prosiding Temu Usaha Pemasyarakatan Teknologi Keramba Jaring Apung Bagi Budidaya Laut. Puslitbang Perikanan-FKPPA Agri Business Club : 172-178.

Sugama. K, dan A. Wijono. 1995. Teknologi pembenihan dan pengadaan benih ikan laut. Prosiding Temu Usaha Pemasyarakatan Teknologi Keramba Jaring Apung Bagi Budidaya Laut. Puslitbang Perikanan-FKPPA Agri Business Club: 120-128. 